\title{
A Liquid Chromatographic Analysis of Gemifloxacin in Pharmaceutical Preparations Using 4-bromomethyl-7- methoxycoumarin Reagent
}

\section{Gemifloksasinin 4-bromometil-7-metoksikumarin Belirteci Kullanılarak Farmasötik Preparatlarda HPLC ile Analizi}

(1) Cem ÖNAL ${ }^{1,2}$

${ }^{1}$ Cinnagen Medicine Company, Project Director, İstanbul, Turkey

2İstanbul Health and Technology University Faculty of Pharmacy, Department of Analytical Chemistry, İstanbul, Turkey

\begin{abstract}
Objective: In this study, analysis of gemifloxacin in pharmaceutical preparations was performed in the presence of 4-bromomethyl-7methoxycoumarin reagent and dibenzo-18-crown- 6 ether catalyst, by high-performance liquid chromatography.

Methods: The excitation wavelength of the compound formed as a result of the derivatization process was found as $\lambda$ ext. $=325 \mathrm{~nm}$ and the emission wavelength as $\lambda \mathrm{em} .=390 \mathrm{~nm}$. Optimum reaction conditions were carefully studied. Chromatographic separations were performed in a $150 \mathrm{~cm} \times 4.6 \mathrm{~mm}, 5 \mu \mathrm{m}$ I.D C18 column, and the mobile phase consisting of acetonitrile: $0.05 \mathrm{M}$ aqueous ammonium acetate $(\mathrm{pH}=5.0)(70: 30, \mathrm{v} / \mathrm{v})$ under flow rate of 1.0 $\mathrm{mL} / \mathrm{min}$.

Results: The calibration curve was found to be linear in the range of $10-200 \mathrm{ng} \cdot \mathrm{mL}^{-1}$. Average recovery was $100.32 \%$ and relative standard deviation values were below $2 \%$.

Conclusion: The method developed has been successfully applied in the analysis of the drug substance in pharmaceutical preparations.

Keywords: Gemifloxacine, liquid chromatography, fluorometric detection, 4-bromomethyl-7-methoxycoumarin, pharmaceutical preparation, validation
\end{abstract}

\section{ÖZ}

Amaç: $\mathrm{Bu}$ çalışmada gemifloksasinin 4-bromometil-7metoksikumarin belirteci ve dibenz-18-taç-6 eter katalizör varlığında farmasötik preparatlarda yüksek performanslı sıvı kromatografisi ile analizi gerçekleştirilmiş̧tir.

Yöntemler: Türevlendirme işlemi sonucu oluşan bileşiğin eksitasyon dalga boyu $\lambda$ ext. $=325 \mathrm{~nm}$ ve emisyon dalga boyu $\lambda \mathrm{em} .=390 \mathrm{~nm}$ olarak bulunmuştur. Optimum reaksiyon şartları dikkatlice çalışıldı. Kromatografik ayırmalar, 250x4,6 mm, $5 \mu \mathrm{m}$ I.D C18 kolonda, asetonitril- $0,05 \mathrm{M}$ sulu amonyum asetat $(\mathrm{pH}=5,0)(70: 30, \mathrm{v} / \mathrm{v})$ mobil fazında, $1 \mathrm{~mL} /$ dak akış hızında gerçekleştirilmiştir.

Bulgular: Kalibrasyon eğrisi $10-200$ ng. $\mathrm{mL}^{-1}$ aralı̆ı̆nda doğrusal bulunmuştur. Ortalama geri kazanım \%100,32 ve bağıl standart sapma değerleri \%2'nin altında bulunmuştur.

Sonuç: Geliştirilen metod, ilaç maddesin farmasötik preparatlardaki analizine başarıyla uygulanmştır.

Anahtar Sözcükler: Gemifloksasin, sivı kromatografisi, florimetrik dedeksiyon, 4-bromometil-7-metoksikumarin, farmasötik preparat

Address for Correspondence: Cem ÖNAL, Cinnagen Medicine Company, Project Director, İstanbul, Turkey

E-mail: cemfox@yahoo.com ORCID ID: orcid.org/0000-0002-5840-7386 


\section{Introduction}

In addition to their gram-negative activity, quinolone antibiotics, which are formed by the addition of fluorine at the six position to the quinolone ring, are also effective in infections with grampositive bacteria. The chemical formula of gemifloxacin (GMF) is $[(\mathrm{R}, \mathrm{S})$-7- [3-aminomethyl-4-methoximino-1-pyrrolidinyl]1-cyclopropyl-6-floro-1,4-dihydro-4-oxo-1,8-naphthyridine-3carboxylic acid (1-4) (Figure 1).

Various methods such as spectrophotometric method $(5,6)$, high performance liquid chromatographic method (HPLC) (7-11), voltammetric method (12) and capillary electrophoretic method (13) have been encountered in the literature for determination of GMF. As a result of literature research, no analysis of GMF using 4-bromomethyl-7-methoxycoumarin (BrMmC) reagent was found. HPLC analysis based on fluorescence measurement gains importance in order to increase the selectivity and sensitivity of the method. The BrMmC reagent is often used for derivatization of molecules containing carboxylic acid functional groups (1416). The aim of this study was to conduct an HPLC analysis based on fluorimetric detection of GMF in pharmaceutical preparations by using 4-bromomethyl-7-methoxycoumarin reagent. This method developed has also been successfully applied in the analysis of pharmaceutical preparations of the drug substance.

\section{Method}

\section{Devices}

Chromatographic separations were performed with the Shimadzu LC 20A (Kyoto, Japan) liquid chromatographic system. The system consists of LC 20 AT Pump, SIL-20AC autosampler, CTO-10A column oven and RF-10AXL fluorescence detector. The excitation wavelength of the compound formed as a result of the derivatization process was found as $\lambda$ ext. $=325 \mathrm{~nm}$ and the emission wavelength as $\lambda \mathrm{em}$. $=390 \mathrm{~nm}$. Chromatographic separations were performed in a $150 \mathrm{~cm}$ x $4.6 \mathrm{~mm}, 5 \mu \mathrm{m}$ I.D C18 column, and the mobile phase consisting of acetonitrile: $0.05 \mathrm{M}$ aqueous ammonium acetate $(\mathrm{pH} 5.0)(70: 30$, v/v) under flow rate of $1.0 \mathrm{~mL} / \mathrm{min}$.

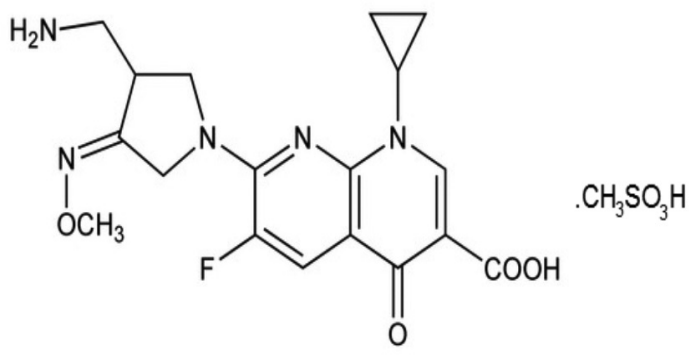

Figure 1. Chemical structure of gemifloxacin mesylate

\section{Reagents and Solutions}

The GMF and its pharmaceutical preparation (Factiva Film Tablet $^{\circledast} 320 \mathrm{mg}$ of GMF) were taken from Abdi Ibrahim Pharmaceuticals (Turkey), and BrMmC and dibenzyo-18crown-6 ether catalyst were purchased from Sigma-Aldrich Chemie (Germany). All chemicals and reagents were used for analytical purity.

\section{Stock Solutions}

For the GMF stock solution, $133.33 \mathrm{mg}$ of GMF mesylate was weighed exactly, dissolved in water in a $100 \mathrm{~mL}$ volumetric flask and made up to its volume (equivalent to $100 \mathrm{mg} / \mathrm{mL}$ GMF base). Standard solutions of GMF were taken from this solution and prepared with water. Stock and standard solutions are stable for about 1 week at $+4{ }^{\circ} \mathrm{C}$. The standard solution of $\mathrm{BrMmC}$ was freshly prepared daily in acetonitrile at a concentration of $100 \mu \mathrm{g} \cdot \mathrm{mL}^{-1}$. Dibenzo-18-crown-6 ether solution was prepared in acetonitrile to make up a volume of $1 \mu \mathrm{g} \cdot \mathrm{mL}^{-1}$.

\section{General Analysis Method}

Two hundred $\mu \mathrm{L}$ BrMmC, $50 \mu \mathrm{L}$ dibenz-18-crown-6 ether solutions and $2 \mathrm{mg} \mathrm{K}_{2} \mathrm{CO}_{3}$ suspension were added to the substance solution (10-200 ng. $\left.\mathrm{mL}^{-1}\right)$ containing different amounts of GMF in $100 \mu \mathrm{L}$ volumes. The resulting mixture was stirred for 2 minutes and then reacted at $70{ }^{\circ} \mathrm{C}$ for 70 minutes. The blank trial was run with $100 \mu \mathrm{L}$ of water as specified in this section. Volumes reached to $1000 \mu \mathrm{L}$ with acetonitrile and then they were injected into the HPLC system.

\section{Analysis Method for Tablets}

The amount equivalent to $250 \mathrm{mg}$ GMF was weighed and dissolved in $125 \mathrm{~mL}$ of water. Then, it was mixed in a mechanical stirrer for 20 minutes and in an ultrasonic bath for 20 minutes, and it was made up to $250 \mathrm{~mL}$ in volume and then filtered through filter paper. The filtrate was diluted with water and studied as specified in the "General Analysis Method". The amount of substance in the tablets was measured using the calibration chart and the corresponding regression equation.

\section{Results}

\section{Determination of Chromatographic Conditions}

Chromatographic conditions were studied in order to develop an HPLC method based on fluorimetric analysis of GMF with $\mathrm{BrMmC}$ reagent. For this purpose, columns such as $\mathrm{C} 18, \mathrm{CN}$ and C8 were tried to determine the most suitable column. Optimal conditions were provided with the following parameters: $250 \times 4.6$ $\mathrm{mm}, 5 \mu \mathrm{m}$ ID C18 column, acetonitrile-0.05 $\mathrm{M}$ aqueous ammonium acetate ( $\mathrm{pH} 5.0)(70: 30, \mathrm{v} / \mathrm{v})$ mobile phase, flow rate at $1 \mathrm{~mL} / \mathrm{min}, \lambda$ ext. $=325 \mathrm{~nm}$ wavelength and $\lambda$ em. $=390$ $\mathrm{nm}$ wavelength. The retention time of the GMF derivative was detected as approximately $3 \mathrm{~min}$ (Figure 2).

\section{Optimization of Derivation Conditions}

In this method developed, GMF was derivatized with 4-bromomethyl-7-methoxycoumarin reagent in the presence 
of dibenz-18-crown- 6 ether catalyst. In order to determine the optimum conditions, the effect of $\mathrm{BrMmC}$ concentration on derivative formation was examined first. It was observed that 200 $\mu \mathrm{L}$ of BrMmC solution (in the presence of $50 \mu \mathrm{L}$ of Dibenzo18-crown-6 ether and $2 \mathrm{mg}$ of $\mathrm{K}_{2} \mathrm{CO}_{3}$ suspension) was sufficient for the derivatization reaction. When the effect of the presence of Dibenzo-18-crown-6 ether on the derivatization reaction was examined, it was observed that the efficiency of the derivative was increased. In order to determine the reaction temperature and reaction time, the reaction mixture was kept at 40, 50, 70 and $80{ }^{\circ} \mathrm{C}$ and for different periods. It was found that the most favorable results were obtained at $70{ }^{\circ} \mathrm{C}$ for 70 minutes (Figure 3). Conditions are given in Table 1.

\section{Method Validation}

The proposed analytical methods were validated according to the ICH guideline Q2 (R1) (17). A calibration curve was generated under the conditions stated above. According to the results obtained, it was observed that the calibration curve was linear in the range of $10-200 \mathrm{ng} \mathrm{mL}^{-1}$. The equation of the measure curve was found as $\mathrm{y}=185.25 \mathrm{x}+2146.2(\mathrm{r} 2=0.9987)$, ( $\mathrm{x}$ concentration is $\mathrm{ng} \mathrm{mL}^{-1}$ and $\mathrm{y}$ is detector response).

The formula of LOD/LOQ $=\kappa S D a / b$ was used to calculate LOD or LOQ. Here the value of $\kappa$ is 3 for LOD and 10 for LOQ. SDa indicates the standard deviation of the scale curve intersept and $\mathrm{b}$ is the slope. The LOD value was $0.0014 \mathrm{ng} \cdot \mathrm{mL}^{-1}$ and the LOQ value was $0.0049 \mathrm{ng} \cdot \mathrm{mL}^{-1}$.

The precision values within day and between days were examined at 10, 100, and $200 \mathrm{ng} \cdot \mathrm{mL}^{-1}$ for five consecutive days. The interday precision was $0.33-0.72 \%$ and the between-days precision was $0.48-0.93 \%$. Results are given in Table 2.

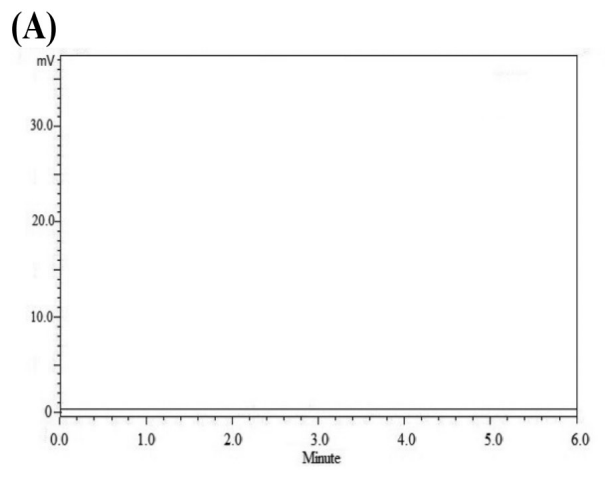

(B)

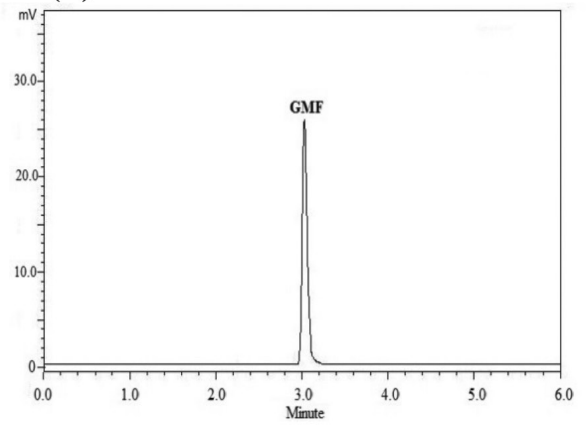

Figure 2. Chromatograms (A) Blank sample (B) GMF added sample (100 ng mL-1)

Table 1. Evaluation of derivatization parameters

\begin{tabular}{|l|l|l|}
\hline Parameter & Range & Optimum value \\
\hline Derivation time (minutes) & $20-100$ & 70 \\
\hline Temperature $\left({ }^{\circ} \mathrm{C}\right)$ & $40-80$ & 70 \\
\hline $\mathrm{L}$ of BrMmC & $25-500$ & 200 \\
\hline $\mathrm{L}$ of Dibenzo-18-crown-6 ether & $10-100$ & 50 \\
\hline $\mathrm{mg}$ of $\mathrm{K}_{2} \mathrm{CO}_{3}$ compound & $0.5-5$ & 2
\end{tabular}

Table 2. Precision values of inter-day and between days

Concentration taken (ng. $\mathrm{mL}^{-1}$ )

\section{Intraday}

10.0

100.0

200.0

Between days

10.0

100.0

200.0

*RSD: Relative standard deviation
Concentration found $\left(\mathrm{ng} \cdot \mathrm{mL}^{-1}\right) \pm \mathrm{SD}$

RSD \%*

\section{$10.09 \pm 0.046$}

$100.14 \pm 0.720$

$200.74 \pm 0.670$
0.46

0.72

0.33

$10.11 \pm 0.046$

0.67

$100.49 \pm 0.930$

0.93

$200.98 \pm 0.970$

\section{.}


The accuracy of the developed methods was examined using the standard addition technique. Standard solutions (10.0, 100.0, 150.0 ng. $\left.\mathrm{mL}^{-1}\right)$ at 3 different concentration levels were added onto the pure analyte sample solution $\left(10 \mathrm{ng} \cdot \mathrm{mL}^{-1}\right)$, mixed and

(A)

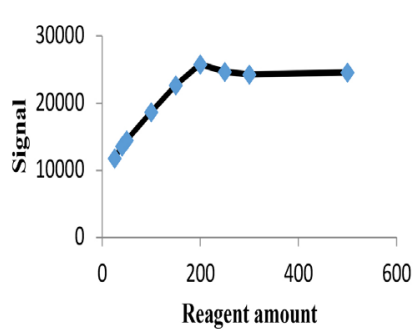

(C)

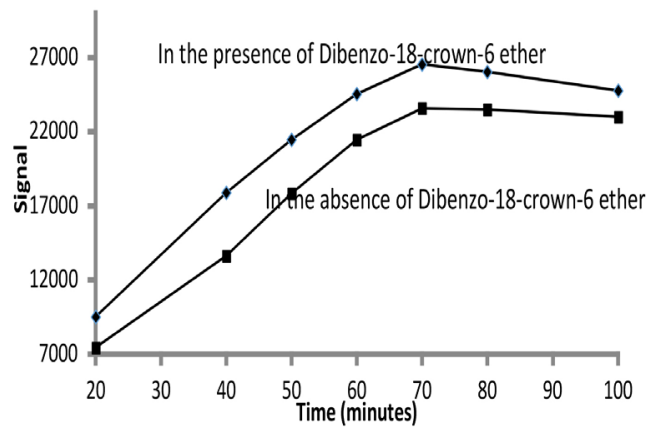

Figure 3. Effects of (A) reagent amount, (B) temperature, (C) reaction time and presence of Dibenzo-18-crown-6 ether on derivatization reaction analyzed. The results obtained are presented in Table 2 . The calculated average recovery percentage was found to be $100.32 \%$ on average. Results are shown in Table 3.

The developed method was also successfully applied in the analysis of the drug substance in pharmaceutical preparations and the results were compared with the spectrofluorimetric method recorded in the literature (5). The results were analyzed in terms of means and precision values using the $t$ and $f$ tests. According to these results, no interference was observed from additives and excipients. The results are given in Table 4.

\section{Conclusion}

In conclusion, in this study, the 4-bromomethyl-7methoxycoumarin reagent used in the analysis of substances containing carboxyl groups was studied for the first time in GMF analysis and the developed HPLC analysis was successfully applied in pharmaceutical preparations of the drug substance. In the developed method, the analysis time was short (approximately 3 minutes) and the LOD and LOQ values were $0.0014 \mathrm{ng} \cdot \mathrm{mL}^{-1}$ and $0.0049 \mathrm{ng} \cdot \mathrm{mL}^{-1}$, respectively. Since the developed method is more sensitive than other methods recorded in the literature, it is planned to be applied in the analysis of biological fluids in the later stages of the study.

\section{Ethics}

Peer-review: Externally peer reviewed.

Financial Disclosure: The authors declared that this study received no financial support.

Table 3. Recovery results

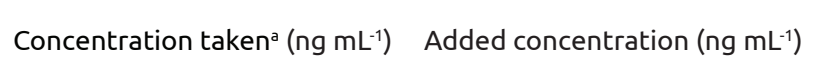

\begin{tabular}{|l|l|}
\hline 10.0 & 10.0 \\
& 100.0 \\
150.0
\end{tabular}

aFactive film tablets $®(320 \mathrm{mg})$

${ }^{\mathrm{b}} \mathrm{n}=5$

'Standard deviation

RSD: Relative standard deviation, SD: Standard deviation
Concentration found ${ }^{\mathrm{b}}\left(\mathrm{ng} \cdot \mathrm{mL}^{-1}\right)$ $\left(\right.$ mean $\left.\pm \mathrm{SD}^{c}\right)$

\section{$20.06 \pm 0.058$}

$110.16 \pm 0.61$

$160.97 \pm 0.86$
Recovery (\%)

\begin{tabular}{l|l}
\hline 100.20 & 0.19 \\
\hline 99.33 & 0.80 \\
100.61 & 0.53
\end{tabular}

Table 4. Analysis of the tablet containing $320 \mathrm{mg}$ GMF $(n=5)$

Amount stated on tablet ${ }^{a}$ (mg/per tablet)

320

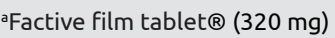

${ }^{\mathrm{b}} \mathrm{n}=5$

'Standard deviation

At the $95 \%$ confidence level, the $t$ value is 2.78 and the $F$ value is 6.39

RSD: Relative standard deviation, SD: Standard deviation

\begin{tabular}{|c|}
\hline $\begin{array}{l}\text { Reference m } \\
\text { recovery (\%) }\end{array}$ \\
\hline $100.15 \pm 0.14$ \\
\hline
\end{tabular}




\section{References}

1. Budavari S. The Merck Index,Merck and Co. Whitehouse Station, NJ, USA: 13th ed, 2001.

2. Völgyi G, Vizserálek G, Takács-Novák K, Avdeef A, Tam KY. Predicting the exposure and antibacterial activity of fluoroquinolones based on physicochemical properties. Eu J Pharm Sci 2012;47:21-7.

3. Oh JI, Paek KS, Ahn MJ, Kim MY, Hong CY, Kim IC, et al. In vitro and in vivo evaluations of LB20304, a new fluoronaphthyridone. Antimicrob Agents Chemother 1996;40:1564-8.

4. Hohl AF, Frei R, Punter V, Graevenitz A, Knapp C, Washington $\mathrm{J}$, et al. International multicenter investigation of LB20304, a new fluoronaphthyridone. Clin Microbiol Infect 1998;4:280-4.

5. Kepekci Tekkeli SE, Önal A. Spectrofluorimetric methods for the determination of gemifloxacin in tablets and spiked plasma samples. J Fluoresc 2011;21:1001-7.

6. Youssef NF, Bebawy LI. Spectrofluorimetric methods for the determination of gemifloxacin mesylate and cefamandole nafate in bulk powder and pharmaceutical preparations. Bulletin of the Faculty of Pharmacy 2006;44:215-27.

7. Rote AR, Pingle SP. Reverse phase-HPLC and HPTLC methods for determination of gemifloxacin mesylate in human plasma. J Chromatogr B 2009;877:3719-23.

8. Al-Hadiya BM, Khady AA, Mostafa GA. Validated liquid chromatographic-fluorescence method for the Quantitation of gemifloxacinin human plasma. Talanta 2010;83:110-6.

9. Kaiser M, Grünspan LD, Costa TD, Tasso L. Reversed phase liquid chromatography method with fluorescence detection of gemifloxacin in rat plasma and its application to the pharmacokinetic study. J Chromatogr B 2011;879:3639-44.

10. Nageswara RR, Naidu ChG, Guru PK, Padiya R, Agwane SB. Determination of gemifloxacin on dried blood spots by hydrophilic interaction liquid chromatography with fluorescence detector: application to pharmacokinetics in rats. Biomed Chromatogr 2012;26:1534-42.

11. Doyle E, Fowles SE, McDonnell DF, White SA Rapid determination of gemifloxacin in human plasma by high performance liquid chromatography-tandem mass spectrometry. J Chromatogr B 2000:746:191-8.

12. Radi AE, Khafagy A, El-Shobaky A, El-Mezayen H. Anodic Voltammetric determination of gemifloxacin using screenprinted carbon electrode J Pharm Anal 2013;3:132-6.

13. Elbashir, AA. Saad, B.. Ali, ASM, Al-Azzam, KMM, AboulEnein HY, Validated stability indicating assay of gemifloxacin and lomefloxacin in tablet formulations by capillary electrophoresis J Liq Chromatogr Relat Technol 2008;31:1465-77.

14. Zacharis CK, Raikos N, Giouvalakis N, Tsoukali-Papadopoulou $\mathrm{H}$, Theodoridis GA. A new method for the HPLC determination of gamma-hydroxybutyric acid (GHB) following derivatization with a coumarin analogue and fluorescence detection: application in the analysis of biological fluids. Talanta 2008;75:356-61.

15. Hulshoff A, Förch AD. Alkylation with alkylhalides as a derivatization method for the gas chromatographic determination of acidic pharmaceuticals. J Chromatogr 1981;220:275-311.

16. Wang K, Nano M, Mulligan T, Bush ED, Edom RW. Derivatization of 5-fluorouracil with 4-bromomethyl-7-methoxycoumarin for determination by liquid chromatography-mass spectrometry. J Am Soc Mass Spectrom 1998;9:970-6.

17. ICH, International Conference on Harmonization of Technical Requirements for Registration of Pharmaceuticals for Human Use, Validation of Analytical Procedures: Text and Methodology Q2 (R1), 2005. 